\title{
Implications of Plant Selectors' Rights for herbage seed production - Plant Varieties Office viewpoint
}

\author{
F. W. WHITMORE \\ Plant Varieties Office, P.O. Box 24, Lincoln
}

\begin{abstract}
The reason for having a Plant Selectors' Rights scheme and some attendant disadvantages are discussed. The development of Rights both internationally and in New Zealand is outlined. Of the 136 applications for New Zealand Rights received to date only one has been for a herbage cultivar. The advent of Rights has not always been welcomed by farmers. It is argued that a Recommended List would complement the Rights scheme. Reference is made to future expansion of Rights in New Zealand.
\end{abstract}

Key words: Plant Selectors' Rights, herbagc seed production, New Zealand.

\section{WHAT ARE PLANT SELECTORS RIGHTS?}

A grant of Plant Selectors' Rights provides similar protection to the breeder of a new plant variety that a copyright provides to the author of a new book or play or a patent provides to an inventor. A grant of Plant Selectors' Rights gives the breeder the exclusive right to sell the seed or reproductive material of the new variety, or he may license others to do this. The breeder or his licensee may also collect a royalty payment on the sale of the seeds or reproductive material.

The term Plant Selectors' Rights as officially used in New Zealand is synonymous with the terms Plant Breeders' Rights or Plant Variety Rights used elsewhere. Another rather confusing point in the world of Plant Selectors' Rights is that the word "variety" has been retained in preference to the word "cultivar", but both are used synonymously.

The release of a new plant cultivar often is the end of a long and costly breeding programme. A grant of Rights helps a breeder to recoup his costs and hopefully to make a profit. A Plant Selectors' Rights scheme, in providing this incentive to breeders, encourages investment in plant breeding activities. This ultimately benefits growers and the economy because of the increased availability of improved cultivars.

What of the disadvantages of Rights? An obvious disadvantage is, of course, the direct cost of administering a scheme. Another is that it may require extra effort on the part of breeders to breed uniqueness into their cultivars just to make them eligible for Rights.

\section{DEVELOPMENT OF PLANT BREEDERS' RIGHTS INTERNATIONALLY}

In the U.S.A., asexually reproduced plants (i.e., plants like roses and some fruit trees, that are reproduced by grafting or budding) have been protected by Plant Patents issued by the U.S. Patent Office since 1930.

Germany has had a system of plant royalties since the 1940s and other European countries independently developed plant protection schemes. In 1961 a number of European countries interested in establishing an international system of Plant Breeders' Rights formed the grouping known as UPOV (the International Union for the Protection of New Varieties of Plants). The UPOV countries developed a system of granting Plant Breeders' Rights after cultivars had been evaluated in official state-run growing trials.

In 1970, the Plant Variety Protection Office was set up in the U.S.A. to administer the granting of rights to sexually-propagated plant varieties. The U.S. system is different from that in UPOV countries in that the Plant Variety Protection Office does not carry out growing trials but instead issues grants following a 
"paper examination" of descriptive and other data supplied by the breeder.

Most countries have hoped for a truly international Plant Breeders' Rights scheme but the differences in operation between the U.S. and UPOV systems seemed to be a barrier. However, in October 1978 a diplomatic conference in Geneva re-wrote the UPOV convention. This, together with some minor alterations in the running of the US. scheme, has closed the gap between the two systems and the U.S.A. is now moving to join UPOV.

\section{DEVELOPMENT OF PLANT SELECTORS RIGHTS IN NEW ZEALAND}

Although there had been interest in New Zealand in Plant Breeders' Rights since the 1950s, it was not until 1973 that the Plant Varieties Act was passed. When the Plant Varieties Regulations were introduced in 1975, the Plant Selectors' Rights scheme came into operation. Initially only roses (Rosa spp.) were eligible for protection but subsequently additional genera or species have been included as shown below:

Barley (Hordeum spp.) October 1975

Perennial ryegrass (herbage type) (Lolium perenne L.) May 1976

Annual ryegrass ( $L$. multiflorum Lam.) January 1977

Potatoes (Solanum tuberosum spp. (uberosum) June 1977

Peas (Pisum strtivum L.) June 1977.
Lucerne (Medicago sativa L.) June 1977

Lotus (Lotus pedunculatus Cav.) September 1977

The New Zealand scheme was developed along UPOV lines with growing trials conducted by the Plant Varieties Office providing the information needed for a decision on granting or declining rights. This system, although very thorough, is expensive to run and the economy of the U.S. system has always appeared attractive.

New Zealand has seen advantages in joining UPOV - joining would strengthen what are already strong trading links with many of the UPOV member countries, it would allow reciprocal rights agreements, exchange of information, assistance with techniques - but New Zealand also hoped for the economy of the U.S. system.

It now appears that we may be able to get the best of both systems.

In June 1979, Cabinet gave approval for New Zealand to apply for UPOV membership and, as it appeared fairly certain that the U.S.A. was also to join UPOV, we in the Plant Varieties Office felt confident that we could change from a system of Plant Variety Office testing to a system of breeder testing - without jeopardizing our chances of being accepted for UPOV membership. This change took effect from August 11979.

There has been prolonged pressure for the New Zealand scheme to be expanded to in-

TABLE 1: N.Z. PLANT VARIETIES OFFICE -TOTAL APPLICATIONS AND GRANTS OF RIGHTS (OCTOBER 1 1979)

\begin{tabular}{|c|c|c|c|c|c|}
\hline & \multicolumn{2}{|c|}{$\begin{array}{l}\text { A pplications } \\
\text { for Rights }\end{array}$} & \multirow[t]{2}{*}{$\begin{array}{l}\text { Decisions } \\
\text { Pending }\end{array}$} & \multicolumn{2}{|c|}{$\begin{array}{l}\text { Grants of Rights } \\
\text { Is sued }\end{array}$} \\
\hline & $\begin{array}{l}\mathrm{NO} \\
\text { Made }\end{array}$ & $\begin{array}{l}\text { N0. } \\
\text { Rejected } \\
\text { or With- } \\
\text { drawn }\end{array}$ & & $\begin{array}{c}\text { No. } \\
\text { Issued }\end{array}$ & $\begin{array}{c}\text { No. } \\
\text { Currently } \\
\text { Valid }\end{array}$ \\
\hline Roses & 94 & 12 & 49 & 33 & 32 \\
\hline Eavley & 15 & 2 & 1 & 12 & 11 \\
\hline Perennial ryegrass & 1 & - & 1 & $=$ & $\rightarrow$ \\
\hline Annual ryegrass & - & - & - & - & $\rightarrow$ \\
\hline Potatoes & 4 & 2 & $\leftarrow$ & 2 & 1 \\
\hline Doas & 20 & 1 & 13 & 6 & 6 \\
\hline Licerne & 2 & - & 2 & - & - \\
\hline lotus & $m$ & - & - & - & - \\
\hline
\end{tabular}


clude many more species. Plant varieties Office staffing has been minimal and prior to August 1979 it was just not possible because of these restraints for the Plant Varieties Office to contemplate further growth. However, the change in August to breeder testing meant that the single Plant Varieties Office technician was able to shed some of his workload and it was possible to extent Rights protection to wheat (Triticum spp.), oats (Avena sativa L.), turnips (Brassica rapa L.), and swedes (B. napus L.).

Table 1, prepared from N.Z. Plant Varieties Office records, summarizes for each of the genera or species protected by N.Z. Plant Selectors' Rights, the number of applications and grants of Rights that have been made. It can be seen that there has been considerable activity with roses, barley and peas, and some interest with potatoes and lucerne. For ryegrasses and lotus the figures would suggest that the impact of Plant Selectors' Rights on New Zealand herbage breeding has been minimal. However, it is too early to draw conclusions. That there are as yet no herbage varieties protected by Plant Selectors' Rights is no doubt a reflection of the fact that the debut of a new cultivar is a comparatively rare event.

In overseas Plant Breeders' Rights schemes, herbage breeders take full advantage of Rights protection.

TABLE 2: U.K. PIAN'T VARIETY RIGHTS OFFICE - TOTAL APPLICATIONS FOR. AND GRANTS OF RIGHTS IN 1978

\begin{tabular}{lcc}
\hline & $\begin{array}{c}\text { Applications } \\
\text { /or Rights }\end{array}$ & $\begin{array}{c}\text { Grunts of } \\
\text { Rights }\end{array}$ \\
\hline Herbage & 97 & 9 \\
Ornamental. fruit & 78 & 48 \\
Crops & 162 & 99 \\
Total & 337 & 156
\end{tabular}

No/c: Because of the time involved in reaching a decision on Rights. the grants of Rights in the second column would tend to relate to applications made in period earlier than 1978.

Table 2 illustrates the interest of herbage breeders in obtaining U.K. rights. There are, of course, many more herbage breeders in the U.K. than in New Zealand. It is interesting that four N.Z. herbage cultivars have U.K. rights.

\section{PLANT SELECTORS' RIGHTS AND THE FARMER}

One thing that herbage seed breeders should be aware of when they produce a seed crop of a protected cultivar is that they will be unable legally to sell seed to another farmer, unless they come to some arrangement with the breeder or his agent.

A point not always clearly understood is that, once Plant Selectors' Rights have been issued for a new cultivar, it is the responsibility of the breeder or his agent to "police" his rights - the involvement of the Plant Varieties Office becomes minimal. To ensure that royalties are paid on all seed sales, the breeder or agent will normally attempt to keep track of sales using a system of merchantfarmer contracts.

Some farmers have voiced the feeling that the breeders and merchants who receive the royalties are benefiting from Plant Selectors' Rights but the farmers are missing out; furthermore, influenced by commercial promotion, farmers may be persuaded into buying higherpriced seed of a protected cultivar which may perform no better than unprotected cultivars.

I would like to comment on this because it raises an important point. It is true that a grant of Rights does not necessarily mean that the protected cultivar is superior, agronomically or otherwise. The grant guarantees only that it is novel, distinct, uniform and stable. I would hope that the protected cultivar would be superior, and that this would compensate or more for the higher cost of the seed. I would suggest that the advent of Plant Selectors' Rights highlights the farmer's need of expert impartial advice on what is the best cultivar for sowing on his farm. The best may or may not be protected. Although some information on herbage species is available from the Acceptable Cultivar Testing Scheme and the N.Z. Bulletin of Cultivars, these sources are not of much immediate help to the farmer making an on-the-spot decision as to which crop or herbage to sow. A Recommended List would provide the assistance and would complement the Plant Selectors' Rights scheme. 
FUTURE GROWTH IN PLANT SELECTORS' There is currently greatest pressure for extendRIGHTS

The current expansion programme will keep Plant Varieties Office staff fully engaged for some time during which it will not be possible to contemplate further expansion.

Once extra finance and extra staff are provided, further expansion can be contemplated. ing protection next to some fruit and ornamentat genera. Of the herbage genera, expansion, when staffing and finance permit, could include amenity perennial ryegrasses, cocksfoot ( Dactylis glomerata L.), amenity Agrostis species and Yorkshire fog (Holcus lanatus L.) . 